\title{
Optimization of customs and tariff policy instruments in the system of import substitution in the agricultural sector
}

\author{
Alexander Kotenev ${ }^{1, *}$, Larisa Ustinova $^{1}$, Galina Zakharova ${ }^{1}$, Alim Otarov $^{1}$, and Natalya \\ Kryzhevskaya ${ }^{1}$ \\ ${ }^{1}$ Stavropol branch of the Krasnodar University of the Ministry of internal affairs of the Russian \\ Federation, 43, Kulakov ave, Stavropol, 355043, Russia
}

\begin{abstract}
In this research authors carried out economic and mathematical modeling of foreign trade activity in order to analyze an impact of applied tariff regulation measures on a level of state economic security taking into account its food component. By formalizing the Grossman-Helpman model, the specifics of interaction between consumers, producers and a state (as participants in the import substitution process) were assessed. The structural components of the model are implemented. A decentralized analysis of the regions was carried out. Algorithmic approaches to the development of regions are formulated. Thus, on the basis of the applied model, differentiation of the regions of the Southern Federal District and North Caucasian Federal District according to the level of import substitution potential, as well as fragmentation of the foreign trade policy applied by the state has been established.
\end{abstract}

\section{Introduction}

One of the basic directions of improving of food security level is an organizational and economic transformation of the mechanism of customs and tariff regulation of foreign trade activities of agricultural producers. Regulation through the use of customs tariff is one of the fundamental mechanisms for improving food security, as it directly affects the level of social welfare, increases the competitiveness of agricultural sector through the use of tariff shelter instruments, and restructures foodstuffs consumption.

Customs and fee policy can be effective only if it promotes production of competitive in price and quality food products, use of modern technologies of production of agricultural products and its complete refining. On the other hand, the high level of technical and technological dependence of domestic agricultural sector on foreign technologies requires selective use of fee policy instruments, as it is impossible to develop agricultural sector without them.

In this regard the improvement of food security requires, on the one hand, improvement of food availability for the population whose standard of living has stoppped to grow, and, on the other hand, adopting a policy of supporting domestic agricultural producer and

\footnotetext{
${ }^{*}$ Corresponding author: sergiiblack@mail.ru
} 
increasing their competitiveness. All of these demand a balanced and deliberated customs and tariff policy in order to achieve a sustainable pattern of economic growth of the national agricultural sector. Specific nature of agricultural industries makes it necessary to take into account a set of factors of a long-term and short-term nature: economic interests of business entities; consumer welfare; import-substituting potential of territorial agricultural sector, etc.

\section{Target setting}

The foreign trade policy of the Russian Federation relating to agricultural products has undergone significant changes since 2014, which were conditioned both by economic and political reasons. Among the main factors that have influenced foreign trade activities and changed trade flows of agricultural products are the following: embargo on import of food products from EU countries, the USA and a number of other countries into Russia since August 2014; drop in the exchange rate of national currency towards major world currencies, especially the US dollar and the euro; joining of Armenia (2014) and Kyrgyzstan (2015) the Customs Union and the EEU.

The food import embargo has fundamentally transformed not only volume but also geographical affairs of foreign trade. The main consequence is rearranging of priorities of "development of the domestic agricultural sector towards import substitution policy" with regard to the main agricultural products: milk and dairy products, meat, vegetables (including protected ground) and other. However, as noted in the report of the Food and Agriculture Organization of the United Nations, based on the latest trade data, the expected import substitution has been replaced by "import replacement," that is, the geographical sources of imports have changed. According to the Federal Customs Service within a year of embargo the volume of imported products from the EU fell by one half, while, for example, imports of agricultural products from Brazil increased by almost 30\% [1-3].

The share of products of agricultural sector in the structure of Russian exports over a period of 2014-2018 remains at a stable level of about 4-6\%, and relating to imports - the share is about $12 \%$. At the same time, after devaluation of the domestic currency, the structure of agricultural exports changed drastically. Since the export prices of cereal in terms of rubles have become much higher than domestic prices, it has led to grain export. As a result, the share of cereal in exports increased to $46 \%$ according to the results of 2014 . The Government of the Russian Federation Introduction introduced the export duty on wheat on February 1, 2015, having reduced the volume of exports, and its share decreased to $28 \%$ by the end of 2015 , i.e. it reached the average over the past seven years.

Transformation of foreign trade flows of food products and import substitution programme have led to an increase in self-sufficiency. Thus, despite the positive changes associated with the increase in food security, the Russian Federation does not have a comprehensive policy on optimization of foreign trade flows of agricultural products, which requires detailed analysis and optimization of the use of customs and tariff policy using mathematical modeling tools.

\section{Model building}

Economic and mathematical models of foreign trade activity can be classified into classical, neoclassical and modern ones.

Classical models are based on Ricardo theory and Heckscher-Ohlin-Samuelson Theorem on equalization of factor prices. Major neoclassical models include Johnson theory of specific factors about trade revenue distribution and standard model of foreign 
trade activity. Almost all models focus on a certain aspect of the economic system functioning. Therefore, their use to formalize a certain process of foreign trade activities requires a specific model. At the same time, they are based on similar prerequisites and have common features, so it can be said that these diverse models are parts of a common standard model of foreign trade activity.

In general, if the market of a single commodity is analysed, it is advisable to use partial equilibrium models. If we consider activities of several industrial complexes, a model of general equilibrium is used.

Among modern approaches to analysis of foreign trade activity, developing a standard model, it is necessary to mention J. Mida TNT-model of exported and non-exported goods, among domestic - V.A. Kolemayev model of foreign trade activity, which develops the theory of general equilibrium. In the first model basic prerequisite is non-exported goods, so a volume of domestic consumption should be equal to the total production. The $\mathrm{V}$. Kolemayev model is an aggregated three-sector model with three types of goods: materials, investment demand goods and consumer goods.

P. Krugman model is of interest, it demonstrates a possibility of having effect of reducing costs or external savings with extensive growth in industry, or the effect of internal savings due to the growth of individual firms for the case of monopolistic competition in industry.

Specific problems of foreign trade policy, which include effective customs and tariff policy in the food security system, can be solved on the basis of above-described models. Empirical studies have shown that losses in inefficient import restriction policies through the use of both tariff and non-tariff methods show a lack of firm conclusion. Measuring the effect of protectionist policies is based on the development of partial equilibrium model and A. Marshall graphical analysis of gains and losses. However, A. Bora and S. Quahara have proved that damage from protectionist measures determined in this way is excessive, as it does not allow to assess the impact of Fee policy and exchange rate. Metzler "ruin tariff" model analyzes specific case where protective import duties contribute to improving foreign trade conditions and reducing domestic prices for imported goods [2]. D. Rial considered the case of the possibility of multiplier effect of industry subsidies based on the use of mathematical methods of game theory.

In the context of objective of this research, it's necessary to consider a possibility of estimating tariff measures on the level of economic security of a country and its food component on the basis of methods of calculation of general equilibrium and econometric models. Their use will reveal common patterns of protectionist policy, such as "import damage," group interests" and so on, as well as determine the impact of certain factors, such as a share of imported goods, a level of technological dependence, labour productivity, etc.

Among the most actively used the Grossman and Helpman model can be distinguished. In their seminal work the authors assessed an impact of a number of factors on tariff policies for imported goods. The positive side of Grossman and Helpman approach is a possibility of analysing of foreign trade activity in terms of industries under the conditions of an open economic system. The main premise of the model is that the interests of certain industry complexes are realized through their lobbying by the largest producers in the industry, who operate through the relevant state authorities, for example, sectoral ministries, which promote the growth of industry import tariffs in order to protect domestic producers.

Analyzing Russian factors of life, S.A. Afontsev broaden the original GrossmanHelpman model and proposed to take into account a factor of non-payment of customs duties by incorrect declaration of imported goods. According to the results, the key priority of state authorities in determining import tariffs is to maximize budget revenue. In addition, 
S.A. Afontsev showed that industry lobby in Russia does not have a significant impact on the value of import tariffs.

\subsection{Formalization of model}

Thus, it is possible to formalize the Grossman-Helpman model for the purpose of analysing modern national customs and tariff policy in the context of food security. It is necessary to assess the specifics of consumer-producer interaction in food markets, interests of authorities in ensuring of import substitution processes with agricultural products, while each party maximizes its benefit functions.

Forms of interaction between agricultural producers and state authorities can be presented as a two-stage non-operational game. At the first stage, representatives of the territorial agricultural sector inform authorities of the maximum possible potential increase in the production of certain food products, which is possible if additional measures of state support are introduced for priority categories of goods. Knowing the current situation in food markets and adequately estimating the available potential, agricultural producer can determine the parameters of the benefit function of the state, so the long-term development strategies of the agricultural sector will also take into account an indicator of growth of economic security in the food sphere [4]. The benefit function of the territorial agricultural sector can be represented as follows:

$$
\mathrm{V}_{\mathrm{i}}=W_{i}-C_{i}
$$

where $C_{\mathrm{i}}$ - import substitution effect of any industry;

$W_{i}$ - general level of industry benefit of the territorial agricultural sector influencing the level of food security which is formed of labor income $L_{i}$, income from the capital $\mathrm{w}_{\mathrm{i}}\left(p_{i}\right)$ which, in turn, directly correlate with the level of prices for import and domestic production, rate of consumer surplus $N^{*} s(p)$ and income from the customs duties" [13] $N^{*} r(p)$ :

$$
W_{i}(p)=l_{i}+\sum_{i=1}^{n} \pi_{i}\left(p_{i}\right)-N[r(p)+s(p)]
$$

The second stage implies that the state authorities, analyzing possible options for organizing foreign trade activity, prescribe import rates for certain food products taking into account interests of domestic agricultural producers and maximizing their own benefit function, in the context of a level of food security. For each branch of the agricultural sector, depending on the acuteness of the problem of import substitution, there are differentiated weighting factors, depending on the contribution of the industry complex of the agricultural sector to food security as a component of the target function of the state authority:

$$
G=\sum_{i \in L} C_{i}(p)+W(p),
$$

where $\sum_{i \in L} C_{i}(p)$ - contribution of each agricultural sector industry to solution of import substitution problem and food security improving;

$W(p)$ - current level of public welfare and food security without stimulating effect of import substitution policy.

According to the proposed model, equilibrium state of certain brunches of the agricultural sector depends on set values of integrated import tariff, which directly correlates with the available industry potential and the level of dependence on imports. If $I$ $=1$, there is a need in import substitution policy on account of increasing import tariffs, which will have a positive impact on food security, otherwise $I=0$.

The Grossman-Helpman model implies that a value of tariffs for imported goods depends on the share of imported products in the industry-wide release of goods $(z)$ and on 
the value of the elasticity index of import scale $\left(t_{i}\right)$ to customs duties (e) [1-3]. In our case, the value of import tariffs in terms of the agricultural sector industries also depends directly on a number of structural parameters: a level of food security for individual commodity groups (a), as well as a need to implemen branch programs of import substitution $\left(a_{L}\right)$ :

$$
t_{-} i /\left(1+t_{-} i\right)=\left(\left(I_{-} i-a_{-} L\right) /\left(a+a_{-} L\right)\right) *\left(z_{-} i / e_{-} i\right)
$$

According to (4), for industries, with potential to import substitution policy implementation, it is advantageous for the state to raise tariffs on imported goods; and for industries with insufficient potential, it is cost-effective to use budgetary subsidies. At the same time, it should be taken into account that "high elasticity for imported goods and its share have inverse dependence with import duty rates value" [1-3]. It is due to the fact that the high share of imported food in the national market in case of increase in customs duties can lead to increase in price of goods, as domestic producers will not be able to replace the volume of falling imports which arise by the impact of increase in prices. The result is a falling living standards and food security, as instead of increasing of the share of domestic products, prices of certain categories of agricultural goods will rise.

Among Russian researchers, who analyze effectiveness of the import substitution policy as a factor that positively affects a level of economic security, a work of A.Yu. Knobel should be noted, who conducted an empirical study on branches of industry [1-4]. The author analyzed factors affecting import tariffs value in the agricultural sector, he allocated the following main factors: a level of monopoly power in the industry, a share of imported products, lobbying opportunities. The results of the study demonstrate inverse dependence between a level of import duties and a level of monopoly power, a share of imports and a size of the labour force.

Estimating the need to use Fee policy instruments in the context of improving food security in the foreign trade policy, we have conducted an empirical testing of the modified equation of the Grossman-Helpman model relating to the hypothesis that the industrial potential of import substitution, the share of imports in food markets, the level of dependence on imported technologies, as well as the investment activity of agricultural producers should be taken into account when establishing import customs duties for agricultural products.

As A.Yu. Knobel notes, in this specification of the Grossman-Helpman model a parameter for a variable which characterize the industry potential of import substitution should be negative [1-4]. It is connected with the fact that implementation of policy of import substitution, on the one hand, demands growth of tariff rates of the customs duties concerning agricultural products, and on the other hand, extreme technical and technological dependence on import demands reduction of tariffs in support industries where agricultural producers act as consumers.

Coefficient value for the industries, which have potential to implementation of policy of "import substitution according to the Grossman-Helpman model, has to be positive. The main reason is that the higher the agricultural output in the agricultural sector, the more income the state has from the increase in tariffs due to the increase in the level of economic security in the food sector "[1-3].

However, one should not take advantage of constant tariff increases cannot be abused, especially in the industries with high concentration of production, where protectionist policy can reduce the efficiency of domestic producers due to the decline in competition in the industry. The result is fall of living standards, breakdown of import substitution policy and diminution of the economic security. 


\section{Model estimating}

Since the domestic agricultural sector is an object of the research, we used as an original array of statistical information data of the Federal Customs Service on separate commodity groups of agricultural products which can be carried to a certain industry complex. This allows to receive more precise results about structure of production of agricultural products, necessary for calculation of $z i$.

We used as dependent variables the ad valorem tariff rates on the main commodity positions in the branches of agricultural sector (1650 positions), where combined rates are used the ad valorem component was taken into account, and in case of fixed rate percentage equivalents of the import duties. All data were taken from the database of the customs statistics on the website of the Federal Customs Service [1-5].

The main problem of the empirical estimating of the model is the estimation of the price elasticity of imports. In accordance with common methods, dynamic analysis is required through the construction of a system of simultaneous equations that describe demand and supply for both imported goods and for domestic substitutes. The quality of Russian statistical information base does not allow to develop such an adequate model, as there is no disaggregated data on individual commodity items for a long period of time.

On this premise we used estimating methodology of short-term elasticity of import demand proposed by S. Afontsev [2]. He conducted assessment of the short-term elasticity of import demand by using statistics on the value recession of imports due to the devaluation of the ruble in 1998. By analogy, we estimated the consequences of the change in food imports that occurred in 2014 due to the ruble depreciation, as the dynamics of change in the national currency rate exceeded the dynamics of change in other factors. Therefore, the change in import volume in 2014 compared to 2015 can be related to the effect of higher import prices. At the same time, it is necessary to take into account the sanctions pressure, which has a high impact on foreign trade policy, and therefore the total volume of imports has been adjusted in terms of food embargo on certain food products from the European Union, the USA, Canada, etc. The descriptive statistics of the base values are shown in the table 1.

Table 1. The descriptive statistics of the base values.

\begin{tabular}{|l|c|c|c|c|}
\hline Variable & Average & $\begin{array}{c}\text { Standard } \\
\text { deviation }\end{array}$ & Minimum & Maximum \\
\hline Import duty rate. \% & 11.3 & 9.3 & 0 & 25.0 \\
\hline $\begin{array}{l}\text { Regional potential of import } \\
\text { substitution. \% }\end{array}$ & 30.5 & 24.8 & 4.4 & 79.2 \\
\hline $\begin{array}{l}\text { Investments share in overoll volume } \\
\text { of shipped product. \% }\end{array}$ & 1.9 & 1.7 & 0.1 & 4.6 \\
\hline
\end{tabular}

According to statistical analysis, despite the complexity of the foreign policy situation, the Russian Federation is following the schedule of reduction of import duties, which was approved after the country's accession to the WTO. On average, import duty rates for almost all commodity groups of agricultural products decreased by $1.5-2.5 \%$ as of the beginning of 2017 and compared to 2014 . Rates range from $0 \%$ (cake) to $25 \%$ (tobaccofree) cigars. The average weighted tariff of import duties on agricultural products is $11.3 \%$, which corresponds to the value fixed in the treaty on the terms of Russia WTO accession.

There are certain distortions in import tariff statistics [2] dew to tariff quotas that apply to certain agricultural goods, list and volume of which are regulated within the legal framework of the Customs Union and Common Free Market Zone, and are subject to approval by the Board of the Eurasian Economic Commission. 
In accordance with WTO requirements, Russia has the right to introduce tariff quotas for imported chilled and frozen cattle meat (code numbers CUCC FEA [Customs Union Commodity Classification of Foreign Economic Activity] 0201 and 0202), pork (code numbers CUCC FEA 0203) and poultry (code numbers CUCC FEA 0207). There is time limit for their use. The use of tariff quotas for cattle meat and poultry ends in 2019 and for pork - in 2020. After that in accordance with WTO requirements, it is necessary to introduce standard import duties not exceeding $25 \%$.

Weighted average of import substitution potential in terms of Southern Federal District and North Caucasian Federal District entities was 30.5\%, which does not allow to conclude that the solution of the problem of improving of food security through the implementation of the import substitution program is possible only at the expense of agricultural producers. own resources. However, it is necessary to take into account the significant differentiation of this indicator by individual entities of Southern Federal District and North Caucasian Federal District, as evidenced by spread in maximum and minimum values. Maximum value of import substitution potential is in the Krasnodar Territory - 79.2\%, and minimum in the Chechen Republic - 4.4\%. More than $50 \%$ of this indicator value of is in the Stavropol Territory (68.1\%) and the Rostov region (63.0\%); in the Volgograd region, the Adyghe Republic and the Kabardino-Balkarian Republic this exceeds a value of standard deviation. Considering the scale of the agricultural sector in the entities of Southern Federal District and North Caucasian Federal District, inference should be drawn that in the largest agrarian regions of southern Russia it is possible to implement the import substitution program, and there will be a maximum effect of the use of instruments of state support of agricultural producers due to their sufficient financial stability and available economic potential.

The need for state support of agricultural producers and its improvement is a very burning problem, as can be seen from the results of the statistical analysis on the "investments share in the overoll volume of shipped product." indicator. Maximum value of this criterion is in the Adyghe Republic and (4.6\%), and minimum - in the Republic of Daghestan and the Chechen Republic $(0.1 \%)$. In the regions with maximum import substitution potential, investments share isas follows: in the Krasnodar Territory $-4.1 \%$, in the Stavropol Territory - 3.4\% and in the Rostov Region - 2.8\%. It is obvious that investment activity in the regional agricultural sector of the Southern Federal District and North Caucasian Federal District does not allow to solve the problem of improving the level of food security independently and requires increased attention from the state.

Parameterization of the modified Grossman-Helpman model with evaluation of the adequacy of the obtained equations was carried out in the Statistica 10 based on the least spreads method [1-3] (table 2). The main conclusions are as follows: speaking about foreign trade policy aimed at supporting domestic agricultural producers through the use of tariff regulation instruments, the accumulated potential of certain agro-industrial sectors in terms of import substitution policy must be considered first of all. Factors characterizing investment activity of agricultural producers have practically no influence on foreign trade activity, therefore cannot be used as approximating ones.

Table 2. Parameterization of the modified Grossman-Helpman model.

\begin{tabular}{|c|c|c|c|}
\hline Parametres & Value & Constant error & \\
\hline \multicolumn{4}{|c|}{ Regional potential of import substitutuion } \\
\hline$\beta_{1}$ & -0.488 & 0.512 & 0.029 \\
\hline$\beta_{2}$ & 0.812 & 0.437 & 0.048 \\
\hline Intercept term & 1.909 & 0.604 & 0.003 \\
\hline \multicolumn{3}{|c|}{$\mathrm{R}^{2}=0.204 ; \mathrm{F}=2.864 ; \mathrm{P}>\mathrm{F}=0.077$. survey number: 13} \\
\hline \multicolumn{4}{|c|}{ Import tariffs of agricultural sector } \\
\hline$\beta_{1}$ & -0.714 & 0.187 & 0.010 \\
\hline
\end{tabular}




\begin{tabular}{|c|c|c|c|}
\hline$\beta_{2}$ & 2.519 & 0.974 & 0.034 \\
\hline Intercept term & 2.914 & 0.248 & 0.015 \\
\hline \multicolumn{3}{|c|}{$\mathrm{R}^{2}=0.362 . \mathrm{F}=4.40 \mathrm{P}>\mathrm{F}=0.0162$. survey number: 1650} \\
\hline \multicolumn{3}{|c|}{ Investments share in overoll volume of shipped product } \\
\hline$\beta_{1}$ & -0.104 & 0.041 & 0.041 \\
\hline$\beta_{2}$ & 0.317 & 0.054 & 0.029 \\
\hline Intercept term & 1.512 & 0.319 & 0.011 \\
\hline \multicolumn{2}{|c|}{$\mathrm{R}^{2}=0.104 . \mathrm{F}=3.87 . \mathrm{P}>\mathrm{F}=0.0126$. survey number: 13} \\
\hline
\end{tabular}

\section{Conclusion}

Instrumental and objective factors can be identified as reasons for small dependency. "The Grossman-Helpman model restrictions are connected with the fact that the least spreads method was used to parameterize it, which assumes a linear relationship between factor and efficient index" [1-3]. Among the objective reasons of an economic nature are the following: the semulated result showed a significant differentiation between the regions of the Southern Federal District and North Caucasian Federal District in the level of import substitution potential, which makes it difficult to carry out econometric analysis due to the high dispersion of the original array of statistical information. It also worth noting fragmented nature of the foreign trade policy of a state, lack of single principles and longterm priorities to support the basic industries of the agricultural sector and sanctions pressure. Through economic security prism and its food component it should be noted that high import tariffs concerning investment goods in the agricultural sector are impossible owing to critical level of dependence of domestic agricultural producers on the foreignmade equipment and technologies as such rate level makes these goods almost inaccessible and reduces financial stability of the enterprises.

Further reform of customs and tariff policy in stimulating import substitution and food security requires a comprehensive assessment of macroeconomic impacts, such as improved basic food availability, development of competitiveness of domestic agricultural producers at global markets, dependence on imports of critical technologies and goods. Thus, foreign trade policy, aimed at improving food security, requires balanced solutions, especially towards customs and tariff policy.

\section{References}

1. J. Gea-Bermúdez, L. Pade, M. Koivisto, H. Ravn, Energy, 191, 116512 (2020). doi: 10.1016/j.energy.2019.116512

2. G. Cederlöf, D. Kingsbury, Political Geography, 72, 124-133 (2019). doi: 10.1016/j.polgeo.2019.04.006

3. L. Hernandez-Santin, P. Erskine, R. Bartolo, Journal Of Cleaner Production, 246, 119079 (2020). doi: 10.1016/j.jclepro.2019.119079

4. N. Logunova, L. Aleksahina, S. Chernyi, 2017 International Conference "Quality Management, Transport And Information Security, Information Technologies" (IT\&QM\&IS) (2017). doi: 10.1109/itmqis.2017.8085781

5. S. Chernyi, N. Logunova, L. Aleksahina, 2017 International Conference "Quality Management,Transport And Information Security, Information Technologies" (IT\&QM\&IS). (2017). doi: 10.1109/itmqis.2017.8085780

6. M. Kiefer, J. Andresen, D. Doubler, A. Pollyea, Journal of Hydrology: Regional Studies, 24, 100606 (2019). doi: 10.1016/j.ejrh.2019.100606 